\title{
GROWTH CHARACTERISTICS OF SHALLOT var. TINOMBO FOLLOWING APPLICATION OF POTASSIUM FERTILIZER AND MANURE ${ }^{1}$
}

\author{
$\operatorname{MUHARDI}^{2 *}$
}

\begin{abstract}
The response of shallot plants to potassium differs substantially depending on the cultivar, organic matter, soil conditions, and weather in the cultivation area. This research aimed to determine some of the growth characteristics of a Tinombo variety of shallot following treatment with an organic fertilizer comprising manure and potassium in the area of Palu, Central Sulawesi. This research took the form of a greenhouse experiment with planting in pots arranged in a completely randomized factorial pattern. The first factor was the application of chicken manure at 0 and 10 tons.ha ${ }^{-1}$, while the second factor was the dose of $\mathrm{KCl}$ fertilizer: $0 \mathrm{~kg} \cdot \mathrm{ha}^{-1} ; 30 \mathrm{~kg} \cdot \mathrm{ha}^{-1} ; 60 \mathrm{~kg} \cdot \mathrm{ha}^{-1}$ and $90 \mathrm{~kg} \mathrm{~K}_{2} \mathrm{O} \cdot \mathrm{ha}^{-1}$. Each treatment was replicated three times. The application of potassium and manure significantly affected the accumulation of dry matter and the linear growth rate of shallot var. Tinombo. Manure applied at 10 tons.ha $^{-1}$ increased the leaf area index when combined with 0 to $60 \mathrm{~kg} \mathrm{~K}_{2} \mathrm{O} \cdot \mathrm{ha}^{-1}$. However, the addition of manure increased the net assimilation rate at all doses of potassium fertilizer. The number of bulbs and harvest index were affected by the amount of manure and potassium fertilizer applied, but there was no significant interaction between these two factors. Applying manure and $\mathrm{K}_{2} \mathrm{O}$ fertilizer resulted in a significantly higher number of bulbs and a better harvest index than in those cases where the two types of fertilizer were not applied.
\end{abstract}

Keywords: Dry matter accumulation. Linear growth rate. Number of bulbs. Harvest index.

\section{CARACTERÍSTICAS DE CRESCIMENTO DE SHALLOT VAR. TINOMBO APÓS APLICAÇÃO DE FERTILIZANTE DE POTÁSSIO E ESTRUME}

RESUMO - A resposta das plantas de chalota ao potássio difere substancialmente dependendo da cultivar, matéria orgânica, condições do solo e clima na área de cultivo. Esta pesquisa teve como objetivo determinar algumas das características de crescimento de uma variedade de chalota Tinombo após o tratamento com um fertilizante orgânico composto por esterco e potássio na área de Palu, Sulawesi Central. Esta pesquisa teve a forma de um experimento em casa de vegetação, com plantio em vasos dispostos em um padrão fatorial inteiramente casualizado. O primeiro fator foi a aplicação de esterco de galinha a 0 e 10 toneladas.ha $^{-1}$, enquanto o segundo fator foi a dose do fertilizante KCl: 0 kg.ha ${ }^{-1} ; 30 \mathrm{~kg} \cdot \mathrm{ha}^{-1}$; $60 \mathrm{~kg} \cdot \mathrm{ha}^{-1}$ e $90 \mathrm{~kg} \mathrm{~K} \mathrm{O}_{2} \cdot \mathrm{ha}^{-1}$. Cada tratamento foi replicado três vezes. A aplicação de potássio e esterco afetou significativamente o acúmulo de matéria seca e a taxa de crescimento linear da chalota var. Tinombo. O esterco aplicado na dose de 10 t.ha $^{-1}$ aumentou o índice de área foliar quando combinado com 0 a $60 \mathrm{~kg} \mathrm{~K} \mathrm{O}_{2} \mathrm{ha}^{-1}$. No entanto, a adição de esterco aumentou a taxa de assimilação líquida em todas as doses de fertilizante potássico. $\mathrm{O}$ número de bulbos e o índice de colheita foram afetados pela quantidade de esterco e fertilizante potássico aplicados, mas não houve interação significativa entre esses dois fatores. A aplicação de esterco e fertilizante $\mathrm{K}_{2} \mathrm{O}$ resultou em um número significativamente maior de bulbos e um melhor índice de colheita do que nos casos em que os dois tipos de fertilizante não foram aplicados.

Palavras-chaves: Acúmulo de matéria seca. Taxa de crescimento linear. Número de bulbos. Índice de colheita.

\footnotetext{
*Corresponding author

${ }^{1}$ Received for publication in 07/18/2020; accepted in 08/09/2021.

${ }^{2}$ Department of Agrotechnology, Agriculture Faculty, Universidade Tadulako, Palu, Indonesia; muhardi_hasanuddin@yahoo.com ORCID: 0000-0002-3722-1144.
} 


\section{INTRODUCTION}

Shallots (Allium ascalonicum L.) are one of the most frequently consumed vegetables in Indonesia and throughout much of the world. Indonesia is a major shallot exporter, ranking fourth worldwide after New Zealand, France, and the Netherlands. In ASEAN, Indonesia ranked first and experienced an increase in harvested area of $3.70 \%$ from 2010 to 2014 compared to the previous year (PUSDATIN, 2015).

Shallots are included in a spices group that cannot be substituted. Shallots are a national priority commodity (KEMENTAN, 2020). Shallot production was 1.52 million tons in 2019. In 2020, its production target was 1.66 million tons, and in 2024 it will increase to 2.13 million tons (KEMENTAN, 2020). Shallot plants are a source of income for farmers, contributing to economic development in several regions of Indonesia (BALITBANGTAN, 2006).

Central Sulawesi is an Indonesian region that produces shallots. Shallot yield has been increasing as a result of superior seeds, balanced fertilization, integrated pest and plant disease control, and proper post-harvest handling. Superior shallot varieties have been identified by farmers, assisted by the government, but their use is often constrained by availability in the field. Thus farmers sometimes have to use a variety that is not suitable for the local environment.

One of the varieties that is quite resistant to dry environments is Tinombo, released by the Minister of Agriculture R.I. in 2004. Tinombo is a local type cultivated by farmers in Central Sulawesi, especially in Palu City, Donggala Regency and Parigi Moutong Regency. It has been valued for its resistance to dry environments and high potential yield, which can reach 11.7 tons of dried bulbs per hectare (DISTAN, 2005).

In addition to genetic factors, environmental factors determine plant productivity. Some environmental conditions can be improved by providing inputs in accordance with limiting environmental factors, such as potassium fertilizers and organic fertilizers. Potassium can improve plant strength and health because it plays an important role in plant physiology, including in the synthesis, transportation, and storage of assimilation products (BUKHSH et al., 2012; HAWKESFORD et al., 2012). Potassium is an important nutrient for shallots in agricultural culture, and several studies have shown that the accumulation of potassium varies according to cultivar and planting location (VIDIGAL; MOREIRA; PEREIRA, 2010; AGUIAR NETO et al., 2014; MARROCOS et al., 2018).

The response of shallot plants to potassium varies widely depending on the cultivar, soil conditions, and climate in the cultivation area Resende, Costa, and Pinto. (2009), Cecílio Filho et al. (2010), and Marrocos et al. (2018) found a range of cultivar behaviors with various $\mathrm{K}$ doses applied to give different shallot yields. Potassium is more absorbable when balanced with organic matter (LYNCH; VORONEY; WARMAN, 2005). Organic matter can improve the physical, chemical, and biological soil (MASTOI et al., 2013). Hussein and Ahmed (2020) showed that applying organic fertilizer can increase plant dry weight, number of bulbs, and potato tuber weight. The aim of the current study was to determine the growth characteristics of the Tinombo shallot following the application of organic manure and potassium fertilizer in the Palu area of Central Sulawesi.

\section{MATERIAL AND METHODS}

Research was conducted in the form of experiments in the greenhouse of the Faculty of Agriculture, Tadulako University, Tadulako Tondo Earth Campus at an altitude of about 75 meters above sea level. The materials used in this experiment were: shallot seeds of the Tinombo variety, chicken manure fertilizer $(\mathrm{M})$, urea fertilizer, SP-36, and $\mathrm{KCl}(\mathrm{K})$. The composition of the fertilizers used was as follows: chicken manure with $\mathrm{N}=1.05 \%, \quad \mathrm{P}_{2} \mathrm{O}_{5}=1.38 \%, \quad \mathrm{~K}_{2} \mathrm{O}=0.81 \%$; urea fertilizer with the chemical formula $\mathrm{CH}_{4} \mathrm{~N}_{2} \mathrm{O}$ or $\left(\mathrm{NH}_{2}\right)_{2} \mathrm{CO}$, nitrogen content $46 \%$, molar mass $60.06 \mathrm{~g} / \mathrm{mol}$, melting point $133{ }^{\circ} \mathrm{C}$, density $1.32 \mathrm{~g} / \mathrm{cm}^{3}$; SP-36 fertilizer with a $\mathrm{P}_{2} \mathrm{O}_{5}$ content of $36 \%, \mathrm{P}_{2} \mathrm{O}_{5}$ content dissolved in citric acid at least $34 \%, \mathrm{P}_{2} \mathrm{O}_{5}$ content dissolved in water at least $30 \%$, maximum water content $5 \%$, free acid content as $\mathrm{H}_{3} \mathrm{PO}_{4}$ maximum $6 \%$, granular form, gray color; and $\mathrm{KCl}$ fertilizer with $60 \% \mathrm{~K}_{2} \mathrm{O}$, melting point $770{ }^{\circ} \mathrm{C}$, boiling point $1,420{ }^{\circ} \mathrm{C}$, molar mass $74.55 \mathrm{~g} / \mathrm{mol}$, density $1.98 \mathrm{~g} / \mathrm{cm}^{3}$, soluble in water and glycerol. Equipment used included a $10-\mathrm{kg}$ capacity scale, analytical balance, sifter, soil tensiometer, measuring cup, oven, and writing stationery.

Experiments in the form of planting in plastic pots (polybag) measuring $30 \times 40 \mathrm{~cm}$ were arranged in a completely randomized factorial design ( $2 \mathrm{M} \times 4 \mathrm{~K}$ ). The first factor was the application of chicken manure at 0 and 10 tons.ha ${ }^{-1}$, while the second factor was the dose of $\mathrm{KCl}$ fertilizer $(60 \%$ $\left.\mathrm{K}_{2} \mathrm{O}\right): 0 \mathrm{~kg} \cdot \mathrm{ha}^{-1} ; 30 \mathrm{~kg} \cdot \mathrm{ha}^{-1} ; 60 \mathrm{~kg} \cdot \mathrm{ha}^{-1}$ and $90 \mathrm{~kg} \cdot \mathrm{ha}^{-1}$ $\mathrm{K}_{2} \mathrm{O}$. There were three replicates of each treatment, and each treatment unit contained 40 pots, giving a total of 960 pots.

The soil used in the experiments was topsoil $(20 \mathrm{~cm})$ from the shallot planting area in Jono Oge village, Donggala Regency. After drying for 2 weeks, the soil was passed through a $2 \mathrm{~mm}$ sieve and 
stirred evenly. The soil was place in pots $(6 \mathrm{~kg}$ of oven-dry weight or $6.25 \mathrm{~kg}$ air-dried, $4.42 \%$ moisture content). Chicken manure, also air-dried, was mixed with the soil in the pots until it was evenly distributed according to the treatment $(0$ and 30 g.pot ${ }^{-1}$ ) before planting. Basic fertilizer and $\mathrm{KCl}$ fertilizer treatment were applied shortly after planting. The basic fertilizers were $200 \mathrm{~kg} \mathrm{~N}^{-1}$ (1.34 g urea.pot $\left.{ }^{-1}\right)$ and $150 \mathrm{P}_{2} \mathrm{O}_{5}\left(1.0 \mathrm{~g} \mathrm{SP}-36\right.$. pot $\left.^{-1}\right)$, respectively. $\mathrm{K}_{2} \mathrm{O}$ fertilizer was given according to the treatment, namely: 0 (K0); $0.15 \mathrm{~g} \mathrm{KCl} \mathrm{pot}^{-1}$ (K1); $0.3 \mathrm{~g} \mathrm{KCl} \mathrm{pot}^{-1}(\mathrm{~K} 2)$ and $0.45 \mathrm{~g} \mathrm{KCl} \cdot \mathrm{pot}^{-1}$ (K3). All artificial fertilizer was applied by immersing it in a hole around the seed, then covering it with soil.

Maintenance included watering and controlling pests/diseases such as bully grass. The benchmark of water provision was to maintain the field capacity in the pot. The field capacity was determined by watering a pot until it was saturated and the water voltage measured using a tensiometer reached $-100 \mathrm{H}_{2} \mathrm{O}$ or -0.1 bar. After reaching field capacity, the pot was weighed to determine the standard weight for correct water provision. No pest attacks or plant diseases were observed during the study.

Shallot plant growth characteristics were assessed by measuring leaf area and dry weight every week beginning 14 days after planting (DAP). Each week observers examined up to 4 pots per unit of the experiment, then leaf samples were taken for measurement of the length of the green part (l) and maximum width $(\mathrm{w})$ so the leaf area could be estimated $(\mathrm{LD}=\mathrm{p} l w / 2)$ (TEI; SCAIFE; AIKMAN, 1996). Measurement of dry weight involved the weight of the leaves and bulbs (roots). Both parts of the plant were cut into small pieces to facilitate drying, then placed in an oven at $70{ }^{\circ} \mathrm{C}$ for 48 hours. Harvesting of plants was carried out at the age of 70
DAP before first being dried. The fresh weight was measured after the bulbs had been separated and cleaned.

Plant growth usually follows a sigmoid curve. It is divided into three phases, namely: (1) the slow phase from germination until the plant starts linear growth is called the lost time, (2) the linear phase, when plant growth is fast and relatively constant, and (3) the aging phase, when growth slows due to the death of plant parts (PARUNTU, 1990). Dry matter production is mathematically estimable using the following relationship (MONTEITH, 1977):

$$
\mathrm{W}_{\mathrm{m}}=\mathrm{C}_{\mathrm{m}} \times \mathrm{t}_{\mathrm{m}}
$$

$\mathrm{W}_{\mathrm{m}}$ : total dry matter production $\left(\mathrm{g} \cdot \mathrm{m}^{-2}\right)$.

$\mathrm{C}_{\mathrm{m}}$ : plant growth rate in a linear period $\left(\mathrm{g} \cdot \mathrm{m}^{-2} \cdot \mathrm{day}^{-1}\right)$. $\mathrm{t}_{\mathrm{m}}$ : long of linear growth period (days).

Operationally, the $\mathrm{C}_{\mathrm{m}}$ and $\mathrm{t}_{\mathrm{m}}$ variables, as well as the lost time $\left(t_{0}\right)$, are obtained from a dry matter accumulation curve measured any time with the help of a regression analysis. The regression coefficient of the curve is the value of $\mathrm{C}_{\mathrm{m}}$, while the values of $t_{0}$ and $t_{m}$ are obtained from the projection of the curve to the $\mathrm{x}$ axis.

The results were analyzed by analysis of variance (ANOVA) at the 5\% level. If the treatment had a significant effect, it was tested further using the Honestly Significant Difference test (Tukey's HSD) at the same level (STEEL; TORRIE, 1989). Observational data on dry matter accumulation of shallots were statistically analyzed at 14,35 , and 70 DAP. Linear growth rate data was obtained according to equation (1) by observing 14 DAP to 70 DAP. Other growth variables reported in this paper include the leaf area index (LAI), net assimilation rate (NAR), and harvest index, calculated using the following equations:

Leaf Area Index $(\mathrm{LAI})=\left(\mathrm{L}_{\mathrm{t}} / \mathrm{G}\right)$

Net Assimilation Rate $\left.(\mathrm{NAR})=\left(\mathrm{W}_{2}-\mathrm{W}_{1}\right) /\left(\mathrm{t}_{2}-\mathrm{t}_{1}\right) \times\left(\ln \mathrm{L}_{2}-\ln \mathrm{L}_{1}\right) / \mathrm{L}_{2}-\mathrm{L}_{1}\right)$

Harvest Index $=$ Weight part of the harvested (economic biomass) $/$ Total weight of the plant

where $\mathrm{W}_{2}=$ plant dry weight at time $t_{2}, \mathrm{~W}_{1}=$ plant dry weight at time $t_{1}, \mathrm{~L}_{2}=$ plant leaf area at time $t_{2}, L_{1}=$ plant leaf area at time $t_{1}, t_{2}=$ time after $t_{1}, t_{1}=$ specific time, and $G=$ surface area (pot).

\section{RESULTS AND DISCUSSION}

\section{Dry Matter Accumulation}

Figure 1 shows the dry matter accumulation during plant growth. Specifically it shows the uniformity of growth at the beginning of the observation period and at 14 to $21 \mathrm{DAP}$; the growth response began to vary between treatments from 28
DAP until the end of the observation period or 70 DAP.

The observational result also showed that the Tinombo shallot, at the age of 14 DAP, only accumulated $4.8 \%(0.17 \pm 0.05)$ of the total dry matter buried during harvest. At the age of 35 DAP or half of the total age, plants had accumulated $41 \%$ of dry matter (1.40 \pm 0.49$)$, as Table 1 illustrates. 

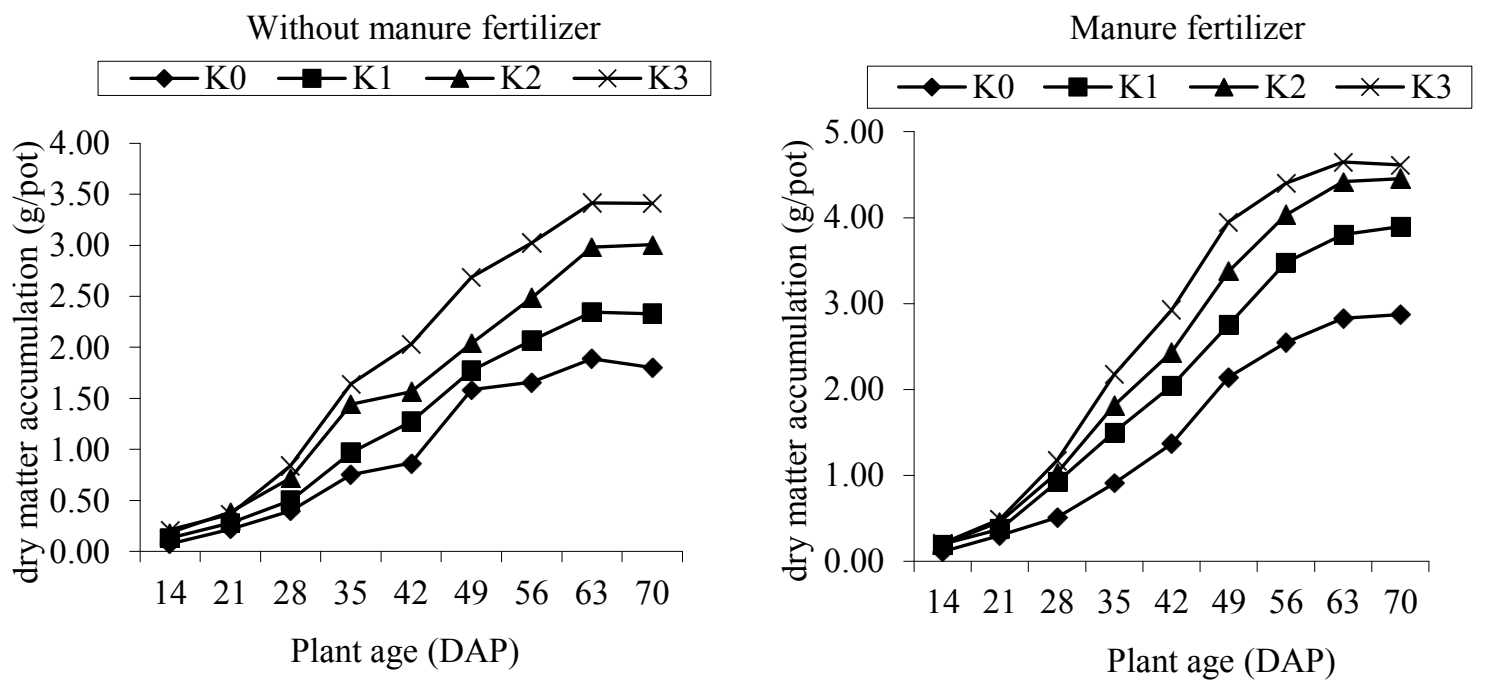

Figure 1. Dry matter accumulation of shallot plants over time.

Table 1. Observational data of dry matter accumulation of shallot.

\begin{tabular}{|c|c|c|c|}
\hline \multirow{2}{*}{ Treatment } & \multicolumn{3}{|c|}{ Plant age (DAP) } \\
\hline & 14 & 35 & 70 \\
\hline Dose of manure fertilizer $\left(\mathrm{t}^{-} \mathrm{ha}^{-1}\right)$ : & & $---\left(\right.$ g.pot $\left.^{-1}\right)----$ & \\
\hline 10 & 0.20 & $1.60 \mathrm{a}$ & $4.08 \mathrm{a}$ \\
\hline 0 & 0.19 & $1.20 \mathrm{~b}$ & $2.76 \mathrm{~b}$ \\
\hline \multicolumn{4}{|l|}{ Dose of $\mathrm{K}_{2} \mathrm{O}\left(\mathrm{kg} \cdot \mathrm{ha}^{-1}\right)$ : } \\
\hline 90 & 0.21 & $1,91 \mathrm{a}$ & $4.16 \mathrm{a}$ \\
\hline 60 & 0.19 & $1,63 \mathrm{a}$ & $3.86 \mathrm{~b}$ \\
\hline 30 & 0.19 & $1,24 b$ & $3.26 \mathrm{c}$ \\
\hline 0 & 0.18 & $0,83 \mathrm{c}$ & $2.39 \mathrm{~d}$ \\
\hline Average & $0.17 \pm 0.05$ & $1.40 \pm 0.49$ & $3.42 \pm 0.98$ \\
\hline
\end{tabular}

Note: Numbers in the same column followed by the same letter do not differ significantly at the $5 \%$ level.

The statistics show there was no interaction effect between the application of manure and $\mathrm{K}_{2} \mathrm{O}$ fertilizer during the experiment, but each treatment had an individual effect on the accumulation of dry matter from 28 DAP. Table 1 shows the results for the beginning, middle, and end periods of growth. By the age of 35 DAP, 10 tons.ha ${ }^{-1}$ of manure had increased the dry matter of plants by $33 \%$, while at 70 DAP or during harvest there was an increase of $48 \%$ in dry matter compared to the dry matter of plants without manure . By 35 DAP, the application of $\mathrm{K}_{2} \mathrm{O}$ fertilizer at doses of 30,60 , and $90 \mathrm{~kg} \cdot \mathrm{ha}^{-1}$ had increased dry matter by $48.7 \%, 95.8 \%$, and $129 \%$, respectively, compared to the dry matter of plants without $\mathrm{K}_{2} \mathrm{O}$ treatment. The accumulation of dry matter increased with each dose of $\mathrm{K}_{2} \mathrm{O}$ by $36.6 \%, 61.6 \%$, and $74.3 \%$ at harvest, which could be partly due to the remobilization and translocation of photosynthates accumulated in bulbs (THANGASAMY, 2016). $\mathrm{K}$ plays a role in photosynthate translocation from the leaves to tuber tissues because $\mathrm{K}$ has a counter ion in the $\mathrm{H}+$ flow across the thylakoid membrane, causing a $\mathrm{pH}$ gradient on the trans-membrane that is needed in ATP synthesis or phosphorylation (ZÖRB; SENBAYRAM; PEITER, 2014; BENDER, HAEGELE, BELOW, 2015; CHANGWEI et al., 2019). The difference between the two sides of this membrane forms a strong chemical potential energy that encourages photophosphorylation (RODRIGUEZ et al., 2013; GUANGLE et al., 2019). Furthermore, photosynthate translocation from source to storage is an active process that needs energy from the photophosphorylation process.

\section{Lost Time $\left(t_{0}\right)$, Linear Growth Period $\left(t_{m}\right)$ and Linear Growth Rate $\left(\mathbf{C}_{\mathrm{m}}\right)$}

Analysis of variance showed that potassium and manure had no significant influence on the time lost $\left(\mathrm{t}_{0}\right)$ and the linear growth period $\left(\mathrm{t}_{\mathrm{m}}\right)$, but each treatment did significantly affect the linear growth rate $\left(\mathrm{C}_{\mathrm{m}}\right)$, despite an insignificant interaction between the two treatment factors tested (Table 2). 
Table 2. Lost Time $\left(\mathrm{t}_{0}\right)$, Linear Growth Period $\left(\mathrm{t}_{\mathrm{m}}\right)$, and Shallot Linear Growth Rate $\left(\mathrm{C}_{\mathrm{m}}\right)$.

\begin{tabular}{cccc}
\hline Treatment & Lost Time, $t_{0}$ (day) & Linear Growth Period, $t_{\mathrm{m}}($ day $)$ & $\begin{array}{c}\text { Linear Growth Rate, } C_{\mathrm{m}} \\
\left(\mathrm{g} \cdot \mathrm{m}^{-2} \cdot \text { day }^{-1}\right)\end{array}$ \\
\hline Dose of manure $($ tons.ha
\end{tabular}

Note: Numbers in the same column followed by the same letter do not differ significantly at the $5 \%$ level.

The linear growth rate is the coefficient of the growth curve slope. In this fast-growing phase, applying 10 tons.ha ${ }^{-1}$ manure significantly increased the linear growth rate by $43.6 \%$. Likewise, applying $\mathrm{K}_{2} \mathrm{O}$ at a dose of 30,60 , and $90 \mathrm{~kg} \cdot \mathrm{ha}^{-1}$ increased linear growth rates by $14.5 \%, 48.4 \%$, and $68.3 \%$ respectively. This is consistent with the findings of Octaviany, Karno, and Fuskhah (2020), who reported that $240 \mathrm{~kg} \mathrm{~K}_{2} \mathrm{O} \mathrm{ha}^{-1}$ increased the growth rate of garlic bulbs. Manure mixed with soil mineral matter influences the soil's water holding capacity, and will increase the amount of $\mathrm{K}$ available to plants (MUNAWAR, 2011). The application of a combination of $\mathrm{KCl}$ and manure increases the growth rate because the soil becomes rich in water and nutrients (NAFI'AH; KARUNIAWAN, 2016).

\section{Leaf Area Index and Net Assimilation Rate}

The leaf area index (LAI) during growth to harvest while applying various doses of potassium fertilizer with and without manure showed a quadratic pattern with different responses. Based on the regression line (Figure 2), potassium dose significantly affected the LAI response pattern with and without the application of manure.

\section{Without manure fertilizer}

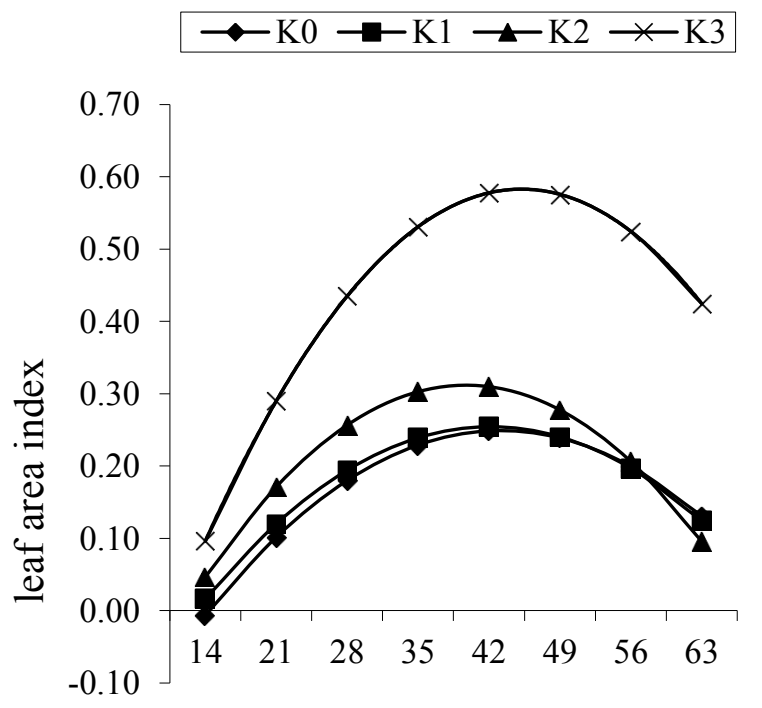

Plant age (DAP)

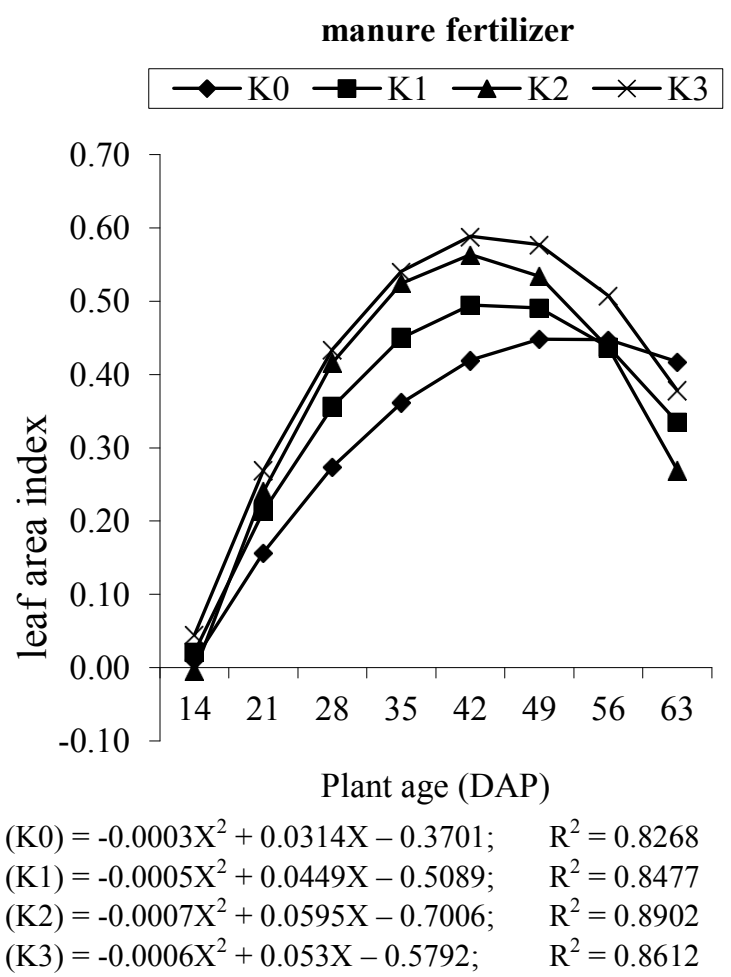

Figure 2. Development of LAI at various doses of potassium fertilizer with and without the application of manure.

Rev. Caatinga, Mossoró, v. 35, n. 1, p. 44 - 52, jan. - mar., 2022 
In the absence of manure, the response of plants to potassium was similar at all doses except 90 kg.ha ${ }^{-1}$. This dose resulted in the highest LAI, which differed significantly from the LAI at lower doses of potassium and the control. The direct effect of potassium on leaf growth is not completely understood, but is related to nitrogen. Potassium fertilization increases the LAI due to its contribution to several chemical processes, e.g., $\mathrm{K}$ increases the uptake of $\mathrm{N}$ by plant roots because $\mathrm{K}$ is an accompanying ion for nitrogen nitrates during transport in the xylem (COELHO et al., 2007). According to Cruz et al. (2007), N application significantly increases leaf area.

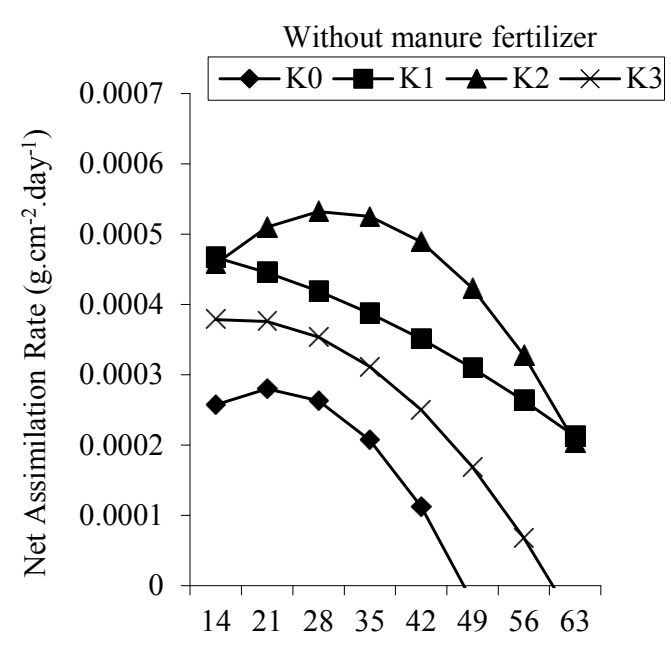

Plant age (DAP)
Figure 2 also shows that the maximum LAI values occurred at 42-49 DAP without manure application, while the maximum LAI was achieved with the application of 10 tons.ha $^{-1}$ of manure, with the curves remaining flat to 49-56 DAP. In other words, the decrease in LAI was slower with than without manure, as organic matter increases the supply of nutrients, particularly $\mathrm{P}, \mathrm{K}$, and $\mathrm{Zn}$ (MANTOVANI et al., 2017).

The net assimilation rate (NAR) curve illustrates the rate of increase in plant dry weight per unit area of leaf per unit of time. Figure 3 displays the weekly NAR curve of the shallot plants in the current study.

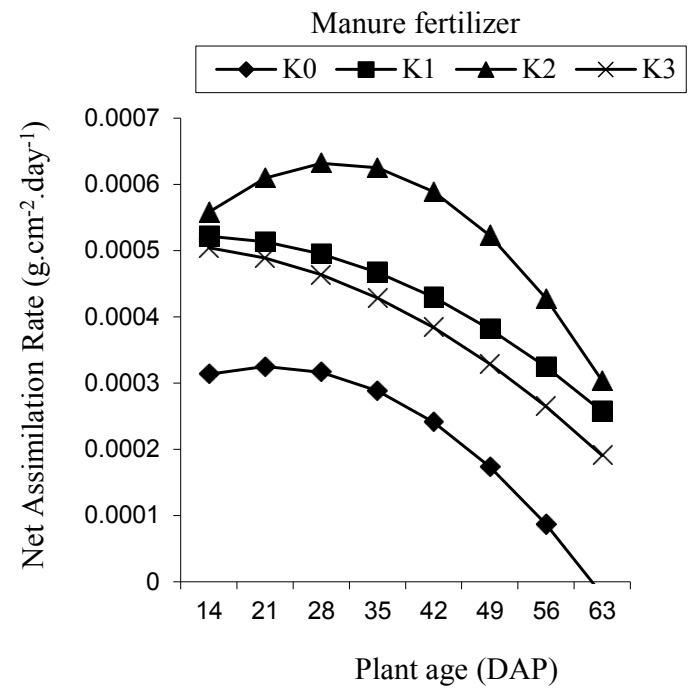

$\mathrm{Y}(\mathrm{K} 0)=-0.0000004 \mathrm{X}^{2}+0.00002 \mathrm{X}+0.00003$ $\mathrm{Y}(\mathrm{K} 1)=-0.00000005 \mathrm{X}^{2}+0.000001 \mathrm{X}+0.0005$; $\mathrm{Y}(\mathrm{K} 2)=-0.0000003 \mathrm{X}^{2}+0.00002 \mathrm{X}+0.0002$;

$\mathrm{Y}(\mathrm{K} 3)=-0.0000002 \mathrm{X}^{2}+0.000008 \mathrm{X}+0.0003$;

$$
\begin{aligned}
& \mathrm{R}^{2}=0.6159 \\
& \mathrm{R}^{2}=0.6694 \\
& \mathrm{R}^{2}=0.8657 \\
& \mathrm{R}^{2}=0.7092
\end{aligned}
$$

\begin{abstract}
$\mathrm{Y}(\mathrm{K} 0)=-0.0000002 \mathrm{X}^{2}+0.00001 \mathrm{X}+0.00002 ;$ $\mathrm{R}^{2}=0.7607$ $\mathrm{Y}(\mathrm{K} 1)=-0.0000001 \mathrm{X}^{2}+0.000003 \mathrm{X}+0.0005$ $\mathrm{R}^{2}=0.7323$ $\mathrm{Y}(\mathrm{K} 2)=-0.0000003 \mathrm{X}^{2}+0.00002 \mathrm{X}+0.0003$

$\mathrm{Y}(\mathrm{K} 3)=-0.0000001 \mathrm{X}^{2}+0.000002 \mathrm{X}+0.0005$

$\mathrm{R}^{2}=0.8315$

$\mathrm{R}^{2}=0.8743$
\end{abstract}

Figure 3. NAR at various doses of potassium fertilizer with and without the application of manure.

Figure 3 shows that the response of plants to the treatment applied was quadratic, with lines that were generally not parallel. Applying $\mathrm{K}$ at a dose of $60 \mathrm{~kg} \cdot \mathrm{ha}^{-1}$ produced the highest NAR, and following application of $\mathrm{K}$ at a dose of $90 \mathrm{~kg} \cdot \mathrm{ha}^{-1}$ there was a decrease in NAR, both with and without manure. However, the application of manure seemed to result in a slower decline in NAR compared to not applying manure. This is consistent with results reported by Abbadi, Gerendas, and Sattelmacher (2008) and Anicésio et al. (2018) for safflower plants treated with different rates of potassium, showing the positive effect of potassium fertilization on the total dry weight of safflower plants.

The application of $\mathrm{K}$ at a dose of $90 \mathrm{~kg} \cdot \mathrm{ha}^{-1}$ tended to decrease the NAR. NAR gives a picture of the amount of photosynthate produced by plants per unit leaf according to area and time. The decrease in photosynthate at high $\mathrm{K}$ doses was a result of high $\mathrm{K}$ concentrations in the soil. These high concentrations may have inhibited the absorption of other nutrients, such as $\mathrm{Mg}$ and $\mathrm{Fe}$, because $\mathrm{K}+$ ions suppress absorption, especially when the $\mathrm{Mg}$ content in the soil is low (MENGEL; KIRKBY, 2001), as in the current study. Simultaneously, the ability of plants to absorb $\mathrm{K}$ could decrease owing to $\mathrm{Mg}$ and $\mathrm{Fe}$ deficiency, leading to a reduction in the active process of ion absorption from soil solutions by roots, which requires energy. 


\section{Number of Bulbs and Harvest Index}

The effects of manure and potassium fertilization on the number of bulbs and shallot harvest index were significant, but there was no significant interaction between these two factors (Table 3).

Table 3 shows that the application of 10 ton.ha $^{-1}$ of manure significantly increased the number of shallot bulbs by 6.5 percent. The application of $\mathrm{K}_{2} \mathrm{O}$ fertilizer at a dose of 30 to
$90 \mathrm{~kg} \cdot \mathrm{ha}^{-1}$ significantly increased the number of bulbs compared to the control (no $\mathrm{K}_{2} \mathrm{O}$ ), with increases ranging from 15.0 to 21.6 percent. The application of $\mathrm{K}_{2} \mathrm{O}$ at a dose of $60 \mathrm{~kg}$.ha ${ }^{-1}$ seemed to produce the highest number of bulbs. The dose that resulted in maximum yields in this experiment $\left(60 \mathrm{~kg} \mathrm{ha} \mathrm{ha}^{-1}\right.$ of $\mathrm{K}_{2} \mathrm{O}$ ) was lower than that recommended by Marrocos et al. (2018), i.e., $180 \mathrm{~kg} \mathrm{ha}^{-1}$ of $\mathrm{K}_{2} \mathrm{O}$ for onion crops in Red Yellow Argisol soils.

Table 3. Number of bulbs and shallot harvest index at different doses of manure and $\mathrm{K}_{2} \mathrm{O}$.

\begin{tabular}{|c|c|c|}
\hline Treatment & Number of bulbs & Harvest index \\
\hline \multicolumn{3}{|c|}{ Dose of manure (tons.ha ${ }^{-1}$ ): } \\
\hline 10 & $7.81 \mathrm{a}$ & $0.83 \mathrm{a}$ \\
\hline 0 & $7.33 b$ & $0.81 \mathrm{~b}$ \\
\hline \multicolumn{3}{|c|}{ Dose of $\mathrm{K}_{2} \mathrm{O}\left(\mathrm{kg} \cdot \mathrm{ha}^{-1}\right)$ : } \\
\hline 60 & $8.11 \mathrm{a}$ & $0.84 \mathrm{a}$ \\
\hline 90 & $7.67 \mathrm{a}$ & $0.82 \mathrm{a}$ \\
\hline 30 & $7.83 \mathrm{a}$ & $0.84 \mathrm{a}$ \\
\hline 0 & $6.67 \mathrm{~b}$ & $0.78 b$ \\
\hline
\end{tabular}

Note: Numbers in the same column followed by the same letter do not differ significantly at the $5 \%$ level.

The shallot plant harvest index was affected by manure and $\mathrm{K}_{2} \mathrm{O}$ fertilizer (Table 3 ). Applying manure significantly increased the harvest index by 2.3 percent compared to the control (no manure). $\mathrm{K}_{2} \mathrm{O}$ at 30 to $90 \mathrm{~kg} \cdot \mathrm{ha}^{-1}$ also significantly increased the harvest index of shallot plants, with an increase of 4.10 to 7.02 percent compared to no application of $\mathrm{K}_{2} \mathrm{O}$, but there was no significant difference between the doses of 30 to $90 \mathrm{~kg} \cdot \mathrm{ha}^{-1}$. Applying $\mathrm{K}_{2} \mathrm{O}$ promoted an increase in the content of $\mathrm{K}$ in the leaf (MARROCOS et al., 2018). Potassium plays a role in photosynthate translocation from leaves to storage (bulbs), helping photosynthates to distribute without accumulating at the photosynthetic site (HARTATI; SURYONO; PURNOMO, 2018). Manure is an important organic material when it comes to increasing the shallot harvest index because it plays a role in improving the physical properties of the soil and increases the content of nutrients, particularly $\mathrm{P}$, $\mathrm{K}$ and Zn (MANTOVANI et al., 2017).

\section{CONCLUSION}

Applying potassium fertilizer and manure significantly affected the accumulation of dry matter of shallot var. Tinombo, but these two treatment factors did not interact significantly. Likewise, potassium fertilization and manure significantly affected the linear growth rate, but again with no significant interaction, while the lost time and the linear growth period remained unaffected by the treatment applied.
Applying 10 tons.ha $^{-1}$ of manure increased the LAI at 0 to $60 \mathrm{~kg} \mathrm{~K}_{2} \mathrm{O} \mathrm{ha}^{-1}$, but not at $90 \mathrm{~kg} \mathrm{~K} \mathrm{~K}_{2} \mathrm{O} \cdot \mathrm{ha}^{-1}$. The addition of manure also increased the NAR at each potassium fertilizer dose. Manure and potassium fertilizers significantly affected the number of bulbs and harvest index. The application of manure increased the number of bulbs by 6.5 percent and the harvest index by 2.3 percent, while $\mathrm{K}_{2} \mathrm{O}$ fertilizer increased the number of bulbs by 15.0 to 21.6 percent and increased the harvest index by 4.10 to 7.02 percent compared to no application of potassium.

\section{REFERENCES}

ABBADI, J.; GERENDAS, J.; SATTELMACHER, B. Effects of potassium supply on growth and yield of safflower as compared to sunflower. Journal of Plant Nutrition and Soil Science, 171: 272-280, 2008.

AGUIAR NETO, P. et al. Crescimento e acúmulo de macronutrientes na cultura da cebola em Baraúna (RN) e Petrolina (PE). Revista Brasileira de Engenharia Agrícola e Ambiental, Campina Grande, 18: 370-380, 2014.

ANICÉSIO, E. C. A. et al. Nitrogen and potassium in safflower: Chlorophyll index, biometric characteristics and water use efficiency. Revista Caatinga, 31: 424-433, 2018. 
BALITBAngtan. Prospek dan Arah Pengembangan Agribisnis Bawang Merah. Jakarta: Badan Penelitian dan Pengembangan Pertanian Kementerian Pertanian. Badan Litbang Pertanian, 2006.

BENDER, R. R.; HAEGELE, J. W; BELOW, F. E. Nutrient uptake, partitioning, and remobilization in modern soybean varieties. Agronomy Journal, 107: 563-573, 2015.

BUKHSH, M. A. et al. Nutritional and physiological significance of potassium application in maize hybrid crop production. Pakistan Journal of Nutrition, 11: 187-202, 2012.

CECÍLIO FILHO, A. B. et al. Produtividade e classificação de bulbos de cebola em função da fertilização nitrogenada e potássica, em semeadura direta. Científica, 38: 14-22, 2010.

CHANGWEI, S. et al. The change in microstructure of petioles and peduncles and transporter gene expression by potassium influences the distribution of nutrients and sugars in pear leaves and fruit. Journal of Plant Physiology, 232: 320-333, 2019.

COELHO, R. I. et al. Resposta à adubação com uréia, cloreto de potássio e ácido bórico em mudas do abacaxizeiro 'Smooth Cayenne'. Revista Brasileira de Fruticultura, 29: 161-165, 2007.

CRUZ, J. L. et al. Níveis de nitrogênio e a taxa fotossintética do mamoeiro "Golden". Ciência Rural, 37: 64-71, 2007.

DISTAN. Laporan Tahunan Sub Dinas Hortikultura. Dinas Pertanian Perkebunan dan Peternakan Provinsi Sulawesi Tengah. Distan Provinsi Sulteng, 2005.

GUANGLE, L. et al. Proton-consumed nanoarchitectures toward sustainable and efficient photophosphorylation. Journal of Colloid and Interface Science, 535: 325-330, 2019.

HARTATI, S.; SURYONO; PURNOMO, D. Effectiveness and efficiency of potassium fertilizer application to increase the production and quality of rice in Entisols. Earth and Environmental Science, 142: 1-8, 2018.

HAWKESFORD, M. et al. Functions of macronutrients. In: MARSCHNER, P. (Ed.). Marschner's mineral nutrition of higher plants. NewYork: Elsevier, 2012. chapter 6, p. 135-178.

HUSSEIN, W. A.; AHMED, N. E. Growth and yield of potato in relation to application of Alphylax and fish oil as organic fertilizers. EurAsian Journal of
BioSciences, 14: 371-375, 2020.

KEMENTAN. Kementan Targetkan Produksi Bawang Merah-Cabai Naik 7 Persen. Ditjen Hortikultura Kementerian Pertanian (Kementan). CNN Indonesia, CNN Indonesia Selasa, 11/02/2020. https://www.cnnindonesia.com/ ekonomi/20200211141353-92-473592/kementantargetkan-produksi-bawang-merah-cabai-naik-7persen.

LYNCH, D. H.; VORONEY, R. P.; WARMAN, P. R. Soil physical properties and organic matter fractions under forages receiving composts, manure or fertilizer. Compost Science \& Utilization, 13: 252-261, 2005

MANTOVANI, J. R. et al. Fertility properties and leafy vegetable production in soils fertilized with cattle manure. Revista Caatinga, 30: 825-836, 2017.

MARROCOS, S. D. T. et al. Potassium fertilization for optimization of onion production. Revista Caatinga, 31: 379-384, 2018.

MASTOI, G. S. et al. Response of field grown hybrid maize to integrated use of inorganic and organic potassium fertilizers. Pakistan journal of agriculture, agricultural engineering \& veterinary sciences, 29: 126-136, 2013.

MENGEL, K.; KIRKBY, E. A. Principles of Plant Nutrition. Kluwer Academic Publishers, Dordrecht, The Netherlands, ISBN No. 079237150X. pp. 849, 2001.

MONTEITH, J. L. Climate. In P. Alvin and T.T. Kozlowski. Ecophysiology of Tropical crops. Academic Press. New York, 1977.

MUNAWAR, A. Kesuburan Tanah dan Nutrisi Tanaman. IPB Press, Bogor. 2011

NAFI'AH, H. G.; KARUNIAWAN, A. Growth rate of five genotypes of sweet potato (Ipomoea batatas L.) are given by combination fertilizer of straw bokashi and potassium on dry land. AGROS, 1: 3147, 2016.

OCTAVIANY, D; KARNO; FUSKHAH, E. The effect of different doses and potassium fertilizer sources on growth rate and formation time of garlic bulbs (Allium sativum L.). Jurnal Pertanian Tropik, 7: 1-7, 2020.

PARUNTU, J. Analisis Tumbuh dan Efisiensi Penggunaan Radiasi Pada Tanaman Jagung. I. Pengaruh Pemupukan Nitrogen. Fakultas Pertanian Universitas Sam Ratulangi, Manado, 1990. 
PUSDATIN. Pusat Data dan Sistem Informasi Pertanian Sekretariat Jenderal- Kementrian Pertanian. Outlook Bawang Merah. Kementerian Pertanian, 2015.

RESENDE, G. M.; COSTA, N. D.; PINTO, J. M. Rendimento e conservação pós-colheita de bulbos de cebola com doses de nitrogênio e potássio. Horticultura Brasileira, 27: 139-143, 2009.

RODRIGUEZ, E. et al. Exposure to Cr (VI) induces organ dependent MSI in two loci related with photophosphorylation and with glutamine metabolism. Journal of Plant Physiology, 170: 534$538,2013$.

STEEL, R. G. D.; TORRIE, J. H. Prinsip dan Prosedur Statistik (Terjemahan). PT. Gramedia, Jakarta, 1989.

TEI, F.; SCAIFE, A.; AIKMAN, D. P. Growth of lettuce, and red beet. 1. Growth analysis, light interception, and radiation use efficiency. Annals of Botany, 78: 633-643, 1996.

THANGASAMY, A. Quantification of dry matter accumulation and nutrient uptake pattern of short day onion (Allium cepa L.). Communications in Soil Science and Plant Analysis, 47: 246-254, 2016.

VIDIGAL, S. M.; MOREIRA, M. A.; PEREIRA, P. R. G. Crescimento e absorção de nutrientes pela planta cebola cultivada no verão por semeadura direta e por transplantio de mudas. Bioscience Journal, Uberlândia, 26: 59-70, 2010.

ZÖRB， C.; SENBAYRAM, M.; PEITER, E. Potassium in agriculture - Status and perspectives. Journal of Plant Physiology, 171: 656-669, 2014. 